\title{
BEETLE ASSEMBLAGE COMPOSITION (COLEOPTERA) ACROSS THE BORBOREMA PLATEAU IN NORTHEASTERN BRAZIL ${ }^{1}$
}

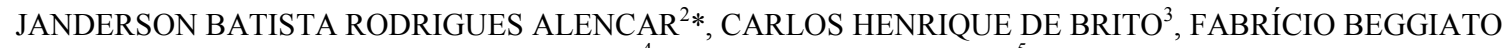 \\ $\mathrm{BACCARO}^{4}, \mathrm{CARLA} \mathrm{DE} \mathrm{LIMA} \mathrm{BICHO}^{5}$
}

\begin{abstract}
The objective of this work was to compare soil beetle (Coleoptera) species composition between two sites on the Borborema Plateau in Northeastern Brazil. We collected 483 individuals belonging to 23 Coleoptera families and 75 species/morphospecies. On the east face of the Borborema Plateau (Areia-PB) we collected a total of 332 individuals representing 58 species/morphospecies and 21 families. On the west face (Cabaceiras-PB) we collected 151 individuals representing 24 species/morphospecies and eight families. Among the 75 total species/morphospecies collected, 51 occurred exclusively on the eastern face of the plateau and 17 occurred exclusively on the west face. Only seven morphospecies were sampled in both areas. The marked difference in beetle assemblage species composition between the west and east sides of the Borborema Plateau suggests that the positioning and climatic variations maintain and promote high levels of beetle diversity in northeastern Brazil.
\end{abstract}

Keywords: Northeastern Brazil. Altitudinal gradientes. Beetle distribution. Orographic effect.

\section{COMPOSIÇÃO DA ASSEMBLEIA DE BESOUROS (COLEOPTERA) NO PLANALTO DA BORBOREMA, NORDESTE DO BRASIL}

RESUMO - O objetivo deste trabalho foi comparar as assembleias de besouros de solo entre dois locais no Planalto da Borborema. Dados de georreferenciamento e climáticos foram usados para comparar as condições locais com as assembleias de besouros. Foram coletados 483 indivíduos, classificados em 75 espécies/ morfoespécies, pertencentes a 23 famílias de Coleoptera. As coletas na face leste do Planalto da Borborema (Areia-PB) totalizaram 332 indivíduos (58 espécies/morfoespécies) pertencentes a 21 famílias. No lado oeste (Cabaceiras-PB) foram coletados 151 indivíduos, 24 espécies/morfoespécies pertencentes a oito famílias. Entre as 75 morfótipos/espécies coletadas, 51 ocorreram exclusivamente na face oriental do Planalto e 17 ocorreram exclusivamente na face oeste. Entre eles, apenas sete morfoespécies foram amostradas em ambas as áreas. A diferença de composição de espécies de besouros entre os lados oeste e leste do Planalto da Borborema sugere que o posicionamento e variações climáticas mantêm e promovem altos níveis de diversidade de besouros no nordeste do Brasil.

Palavras-chave: Nordeste. Clima. Distribuição de besouros. Efeito orográfico.

\footnotetext{
*Corresponding author

${ }^{1}$ Received for publication in 08/11/2020; accepted in 09/06/2021.

Paper extracted from the TCC of the first author.

${ }^{2}$ Department of Entomology, Instituto Nacional de Pesquisas da Amazônia, Manaus, AM, Brazil; jandersonrn@gmail.com - ORCID: 00000001-9482-7866.

${ }^{3}$ Departament of Biological Sciences, Universidade Federal da Paraíba, Areia, PB, Brazil; carlos@cca.ufpb.br - ORCID: 0000-0002-01950986.

${ }^{4}$ Departament of Biological Sciences, Universadade Federal do Amazonas, Manaus, AM, Brazil; fbaccaro.ecolab@gmail.com - ORCID: 0000-0003-4747-1857.

${ }^{5}$ Departament of Biological Sciences, Universidade Estadual da Paraíba, Campina Grande, PB, Brazil; clbicho@gmail.com - ORCID: 0000 $-0001-6801-8395$.
} 


\section{INTRODUCTION}

The orographic effect is an important driver of climate. Mountains force air masses upward, cooling the air and resulting in precipitation on the windward side. By the time the air mass crosses the mountain, it has lost most of its moisture, resulting in less precipitation on the leeward side of mountain or range (ROE, 2005; JUNQUAS et al., 2016). The orographic effect, therefore, promotes changes in temperature and humidity, which may affect species distribution (GUEDES ALCOFORADO-FILHO et al., 2003; ANDRADE et al., 2006; OLIVEIRA; ANDRADE; FÉLIX, 2006). This phenomenon occurs on the coast of Northeastern Brazil (UVO; BERNDTSSON, 1996; LYRA; OLIVEIRAJÚNIOR; ZERI, 2014). However, how this process shapes soil beetle species assemblages still unknown.

The Borborema Plateau is considered one of the most important orographic features in Northeastern Brazil, shaping hydrography and climate (EMBRAPA, 1972). The vegetation of this region is highly variable, from the Caatinga (GUEDES ALCOFORADO-FILHO et al., 2003) to the Ombrophilous forests (ANDRADE et al., 2006; OLIVEIRA; ANDRADE; FÉLIX, 2006). The region lacks taxonomic information (Linnean Shortfall) and records of species' distributions (Wallacean Shortfall). However, the few studies on buprestids (IANNUZZI; MAIA; VASCONCELOS, 2007); seasonal variation of insect orders (VASCONCELLOS et al., 2010); galling insects (SANTOS; ALMEIDA-CORTEZ; FERNANDES, 2011); treehopper diversity (CREÃO-DUARTE et al., 2016; ROTHEÁ et al., 2019) and the temporal and spatial patterns of dung beetles in semiarid regions (HERNÁNDEZ, 2007; LIBERAL et al., 2011), indicate a relative high insect species richness.

In tropical mountains, the species occurrence tends to be restricted to certain altitude ranges. This pattern is based on species responses to climatic variation, which is often correlated with altitude
(JANZEN, 1967; JANZEN et al., 1976; RANGEL et al., 2018; RAHBEK et al., 2019). Thus far, a comprehensive assessment of Coleoptera diversity along a gradient of climatic variation in the Borborema Plateau has not been conducted. It is likely that differences in climatic characteristics between the east and west of the Borborema Plateau affect the distribution of soil beetle species. The objective of this work was therefore to compare the beetle species assemblage between these areas. Specifically, we address the following questions: (1) How many beetles species are found on both the east and west face of the plateau? (2) How does the richness and abundance of beetle species vary between the west and east side of the plateau? and (3) How does beetle species composition change at the outer edges of this east-west gradient? A dearth of taxonomic information is recognised as one of the major obstacles in the conservation of biodiversity in Northeast Brazil (COLEMAN, 2015; HORTAL et al., 2015), and information about species distribution and assemblage composition are crucial to land management and conservation best practices.

\section{MATERIAL AND METHODS}

Beetles were studied in two areas, located 85 $\mathrm{km}$ apart, on the Borborema Plateau (Figure 1). One site is located on the east plateau at Mata do PauFerro State Ecological Reserve (REMPF) (6 ${ }^{\circ} 57$ 'S; $35^{\circ} 44^{\prime} \mathrm{W}$ ) (Figure 1) managed by the Superintendência de Administração do Meio Ambiente (SUDEMA) in a remaining section of the Open Ombrophilous Forest (VELOSO; RANGEL FILHO; LIMA, 1991), and ranges in altitude from 552 to $662 \mathrm{~m}$. The Reserve has a total area of $\sim 600$ hectares and is part of the Areia municipality in Paraíba. The average temperature at this site during the study period was $22^{\circ} \mathrm{C}$, with a maximum of $23.93^{\circ} \mathrm{C}$ and a minimum of $19.76^{\circ} \mathrm{C}$. The relative humidity is around $85 \%$ and the annual precipitation is 1,400 mm (MAYO; FEVEREIRO, 1982).

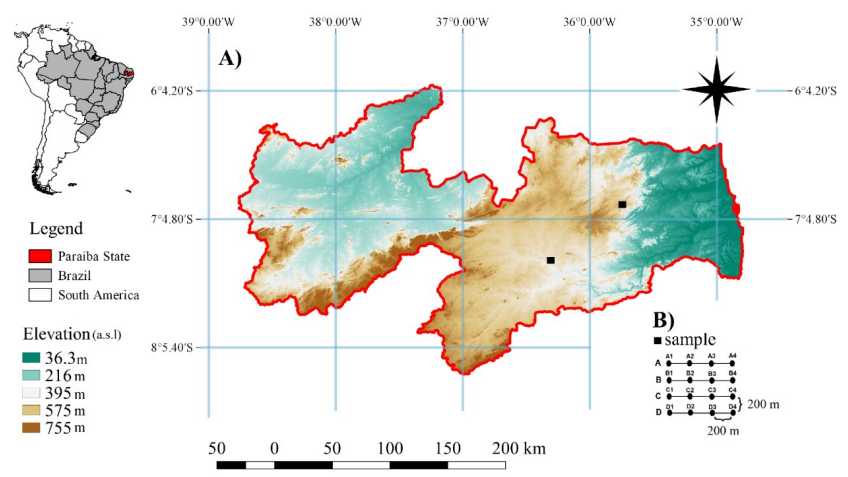

Figure 1. A) Topographic variation and B) Location of the sampling design on the east (Mata do Pau Ferro State Reserve) and west (São Francisco rural community) and west (São Francisco rural community) faces of the Borborema Plateau, Paraíba, Brazil. The data used were DEM (digital elevation model), SRTM (shuttle radar topography mission) from project TOPODATA/INPE with $30 \mathrm{~m}$ resolution, available at: http://www.dsr.inpe.br/topodata/acesso.php. 
The second site is located on the west plateau, in the rural community of San Francisco $\left(7^{\circ} 24^{\prime} \mathrm{S}\right.$; $\left.36^{\circ} 18^{\prime} \mathrm{W}\right)$, in Cabaceiras municipality, Paraíba (Figure 1). The area is not a conservation unit, but has never been explored beyond extensive goat breeding raising that occurs at low density (1.5 goats/ha) (PARENTE et al., 2010). The landscape at this site is typical for the Caatinga (ANDRADELIMA, 1981), ranging in altitude from 427 to $463 \mathrm{~m}$. During the study period, the average temperature was $24^{\circ} \mathrm{C}$, with a maximum $27.32^{\circ} \mathrm{C}$ and minimum of $21.43^{\circ} \mathrm{C}$, and relative humidity of $68.8 \%$. The annual rainfall average is $336.6 \mathrm{~mm}$ based in 86 years of observation (BORGES et al., 2012; INMET, 2017).

\section{Experimental design and beetle sampling}

Beetle specimens collected from the traps were identified and morphotyped using identification keys (LUEDERWALDT, 1931; GIDASPOW, 1963; WATT, 1974; ARNETT; THOMAS 2000, 2002; TRIPLEHORN; JOHNSON; BORROR, 2005; SOULA, 2009; VAZ-DE-MELLO et al., 2011;
SILVEIRA; MERMUDES, 2014; CELLI et al., 2015; SPIESSBERGER; MERMUDES 2018; HUCHET; COSTA-SILVA 2018; NASCIMENTO; BOTERO 2018; RATCLIFFE, 2018; SOUSA, 2019) and expert assistance. Specimens were deposited in the collection of the to the Laboratory of Invertebrate (LABIN) of the Centro de Ciências Agrárias of the Universidade Federal da Paraiba, Campus II Areia/PB.

\section{Environmental variables}

To test the effect of environmental variables on species occurrence, richness and abundance, five possible predictors were selected: total monthly precipitation $(\mathrm{mm})$, monthly minimum temperature average $\left({ }^{\circ} \mathrm{C}\right)$, monthly maximum temperature average $\left({ }^{\circ} \mathrm{C}\right)$, and monthly relative humidity average $(\%)$. The climate data were obtained from the Instituto Nacional de Meteorologia (INMET) Sensors are located about $9.3 \mathrm{~km}$ from the rural community of San Francisco and $3.8 \mathrm{~km}$ from REMPF (Table 1).

Table 1. Monthly averages of climate variables of sampled areas, data from the Instituto Nacional de Meteorologia (INMET).

\begin{tabular}{|c|c|c|c|c|c|c|c|c|c|c|c|c|}
\hline \multirow{2}{*}{ Cabaceiras-PB } & \multicolumn{7}{|c|}{2011} & \multicolumn{5}{|c|}{2012} \\
\hline & Jun & Jul & Aug & Sep & Oct & Nov & Dec & Jan & Feb & Mar & Apr & May \\
\hline Precipitation & 42.60 & 17.80 & 10.40 & 0.00 & 0.20 & 1.40 & 0.20 & 1.40 & 0.80 & 3.60 & 1.20 & 15.80 \\
\hline Air humidity & 80.34 & 83.72 & 75.68 & 67.38 & 64.62 & 64.67 & 60.79 & 67.10 & 67.80 & 64.50 & 62.16 & 66.51 \\
\hline $\begin{array}{l}\text { Maximum } \\
\text { temperature }\end{array}$ & 23.74 & 22.48 & 23.26 & 24.35 & 26.17 & 26.64 & 27.32 & 26.55 & 26.27 & 26.96 & 27.28 & 26.22 \\
\hline $\begin{array}{l}\text { Minimum } \\
\text { temperature }\end{array}$ & 22.66 & 21.43 & 22.00 & 22.90 & 24.77 & 25.27 & 25.90 & 25.24 & 25.01 & 25.57 & 25.89 & 24.88 \\
\hline \multirow{2}{*}{ Areia-PB } & \multicolumn{7}{|c|}{2011} & \multicolumn{5}{|c|}{2012} \\
\hline & Jun & Jul & Aug & Sep & Oct & Nov & Dec & Jan & Feb & Mar & Apr & May \\
\hline Precipitation & 188.40 & 387.00 & 136.80 & 21.80 & 15.00 & 49.80 & 30.00 & 179.40 & 149.60 & 36.80 & 33.00 & 110.40 \\
\hline Air humidity & 92.44 & 93.75 & 92.00 & 85.58 & 85.16 & 84.60 & 82.36 & 87.24 & 87.98 & 85.96 & 83.25 & 86.02 \\
\hline $\begin{array}{l}\text { Maximum } \\
\text { temperature }\end{array}$ & 21.56 & 20.45 & 20.85 & 21.34 & 22.73 & 23.24 & 23.75 & 23.11 & 22.95 & 23.93 & 23.93 & 23.10 \\
\hline $\begin{array}{l}\text { Minimum } \\
\text { temperature }\end{array}$ & 20.83 & 19.76 & 20.01 & 20.40 & 21.69 & 22.15 & 22.63 & 22.12 & 22.04 & 22.55 & 22.89 & 22.11 \\
\hline
\end{tabular}

\section{Statistical Analysis}

Preliminary analysis showed that all climatic variables (Table 1) were strongly correlated (r Pearson $>0.6$, Figure 5). Therefore, we opted to use site as the predictor variable (proxy for climatic variables) in the models. An individual generalised linear mixed model (GLMM) (BOLKER et al., 2009) was constructed for Coleoptera species richness and abundance against "site" (Areia and Cabaceiras) as the explanatory variable. We adopted Poisson error distribution and included "transect" nested in "month" as random effects in the model to control for spatial and temporal dependence on these 
data. To validate the model fit, we compared the Akaike Information Criterion (AIC) of each GLMM with the respective AIC of the null model (intercept and random effects only). Full GLMM models were selected when the delta AIC (difference between full and null models) were $>2$ (AKAIKE, 1982). We calculated the marginal and conditional $\mathrm{R}^{2}$ for each GLMM to measure the importance of the random variables in our results. Marginal $\mathrm{R}^{2}$ provides the variation explained only by the fixed variables, while the conditional $\mathrm{R}^{2}$ gives the variation explained by fixed and random effects in the model (NAKAGAWA; SCHIELZETH, 2013).

We also created rarefaction plots for both sites. Rarefaction methods calculate the expected number of species based on a random subsample of the data, making the comparisons among sites more reliable (GOTELLI; COLWELL, 2001). We used the Mao Tao's analytical method to generate valid $95 \%$ confidence intervals for the rarefaction curves, which do not converge to zero at the maximum sample size (COLWELL et al., 2004).

We used a permutational multivariate analysis of variance (PERMANOVA), based on Bray-Curtis distances of standardised diversity data, to evaluate the effects of "site" on coleopterans species composition. This analysis allows simultaneous testing of multiple factors and covariates based on permutation tests (ANDERSON, 2001). We created a stratified permutation procedure, with "transect" nested in "month". Therefore, randomisations occur only between transects from different months and not within transects sampled in the same month. The statistical probabilities of PERMANOVA were based in 999 permutations. All analyses were carried out in R 3.2.3 (R CORE TEAM, 2019). GLMM models were created with lme 4 package (BATES et al., 2015) and residual analysis was done using the DHARMa package (HARTIG, 2016). PERMANOVA was created using the function adonis from the vegan package.

\section{RESULTS AND DISCUSSIONS}

During the study period the eastern plateau (Areia) site had higher annual precipitation $(1,338$ $\mathrm{mm})$, higher relative monthly humidity $(87 \%)$ and lower monthly mean temperatures maximum $\left(22.6^{\circ} \mathrm{C}\right)$ and minimum $\left(21.6^{\circ} \mathrm{C}\right)$ than the western area (Cabaceiras), which had an annual precipitation of $95.4 \mathrm{~mm}$, a monthly relative humidity of $68.8 \%$ and monthly temperature maximum of $25.6^{\circ} \mathrm{C}$ and minimum $24.3^{\circ} \mathrm{C}$. The proximity of the Borborema Plateau to the Atlantic Ocean results in higher rainfall and more stable and milder temperatures on the eastern side of the plateau than on the western side (leeward) (ROE, 2005).

We captured 483 individuals, classified into 75 species/morphospecies, belonging to 23 Coleoptera families. The collections on Borborema eastern Plateau (Areia) totalled 332 individuals (58 species/morphospecies) belonging to 21 families. On the western side (Cabaceiras), 151 individuals were collected, belonging to 24 species/morphospecies and eight families. Seven common species were collected in both localities. Due to a lack of taxonomic information on the species of Northeastern Brazil, only 44 specimens were identified to the generic/specific level, and remaining specimens could be identified to tribe or family only (Table 2).

Table 2. List of species and morphospecies of beetles recorded on the east (Areia-PB) and west (Cabaceiras-PB) faces of the Borborema Plateau, Paraiba State, Brazil.

\begin{tabular}{lcccc}
\hline Anobiidae & East & West & Total \\
\hline Anobiidae sp. 10 & 1 & & 1 \\
\hline Anthicidae & East & West & Total \\
\hline Anthicidae sp. 76 & & 3 & 3 \\
\hline Bolboceratidae & East & West & Total \\
\hline Neoathyreus sp. 56 & 1 & & 1 \\
\hline Brentidae & East & West & Total \\
\hline Paratrachelizus sp. 55 & 1 & & 1 \\
\hline Carabidae & East & West & Total \\
\hline Brachygnathus sp. 87 & & 3 & 3 \\
Calosoma $($ Castrida $)$ alternans granulatum Perty, 1830 & 1 & & 1 \\
Carabidae sp. 46 & 1 & & 1 \\
\hline
\end{tabular}


Table 2. Continuation.

\begin{tabular}{|c|c|c|c|}
\hline Carabidae & East & West & Total \\
\hline Carabidae sp. 48 & 1 & & 1 \\
\hline Carabidae sp. 79 & & 1 & 1 \\
\hline Carabidae sp. 81 & & 2 & 2 \\
\hline Carabidae sp. 86 & & 3 & 3 \\
\hline Carabidae sp. 88 & & 1 & 1 \\
\hline Dercylus sp. 9 & 6 & & 6 \\
\hline Galerita sp. 84 & & 4 & 4 \\
\hline Tetracha brasiliensis (Kirby, 1819) & & 2 & 2 \\
\hline Notiobia sp. 1 & & 36 & 36 \\
\hline Notiobia sp. 2 & & 12 & 12 \\
\hline Odontocheila nitidicollis (Dejean, 1825) & 1 & & 1 \\
\hline Scarites sp. 14 & 7 & 9 & 16 \\
\hline Cerambycidae & East & West & Total \\
\hline Chlorida festiva (Linnaeus, 1758) & 1 & & 1 \\
\hline Jupoata rufipennis (Gory, 1831) & 7 & & 7 \\
\hline Leptostylus sp. 70 & 1 & & 1 \\
\hline Mallodon spinibarbis (Linnaeus, 1758) & 1 & & 1 \\
\hline Oreodera sp. 57 & 1 & & 1 \\
\hline Cetoniidae & East & West & Total \\
\hline Gymnetis aurantivittae Ratcliffe, 2018 & 1 & & 1 \\
\hline Inca clathratus (Olivier, 1792) & 2 & & 2 \\
\hline Chrysomelidae & East & West & Total \\
\hline Bruchinae sp. 24 & 1 & & 1 \\
\hline Eumolpinae sp. 36 & 1 & & 1 \\
\hline Galerucinae sp. 16 & 1 & & 1 \\
\hline Hispinae sp. 50 & 1 & & 1 \\
\hline Coccinellidae & East & West & Total \\
\hline Coccinella sp. 90 & & 1 & 1 \\
\hline Curculionidae & East & West & Total \\
\hline Curculionidae sp. 34 & 3 & & 3 \\
\hline Curculionidae sp. 41 & 3 & & 3 \\
\hline Curculionidae sp. 42 & 2 & 3 & 5 \\
\hline Curculionidae sp. 44 & 1 & & 1 \\
\hline Curculionidae sp. 45 & 4 & & 4 \\
\hline Curculionidae sp. 47 & 1 & & 1 \\
\hline Curculionidae sp. 53 & 9 & & 9 \\
\hline Curculionidae sp. 61 & 2 & & 2 \\
\hline Curculionidae sp. 66 & 16 & & 16 \\
\hline Curculionidae sp. 80 & 2 & 1 & 3 \\
\hline
\end{tabular}

Rev. Caatinga, Mossoró, v. 35, n. 1, p. 148 - 159, jan. - mar., 2022 
Table 2. Continuation.

\begin{tabular}{|c|c|c|c|}
\hline Curculionidae & East & West & Total \\
\hline Curculionidae sp. 91 & & 8 & 8 \\
\hline Platypodinae sp. 58 & 1 & & 1 \\
\hline Scolytinae sp. 18 & 3 & & 3 \\
\hline Elateridae & East & West & Total \\
\hline Elateridae sp. 23 & 1 & 1 & 2 \\
\hline Erotylidae & East & West & Total \\
\hline Episcapha sp. 11 & 1 & & 1 \\
\hline Episcapha sp. 54 & 1 & & 1 \\
\hline Episcapha sp. 65 & 3 & & 3 \\
\hline Histeridae & East & West & Total \\
\hline Omalodes (Omalodes) foveola Erichson, 1834 & 1 & & 1 \\
\hline Lampyridae & East & West & Total \\
\hline Amydetes sp. 17 & 1 & & 1 \\
\hline Leiodidae & East & West & Total \\
\hline Leiodidae sp. 20 & 1 & & 1 \\
\hline Melolonthidae & East & West & Total \\
\hline Ancistrosoma sp.1 & 2 & 1 & 3 \\
\hline Cyclocephala sp. 89 & & 11 & 11 \\
\hline Dyscinetus dubius (Olivier, 1789) & 23 & & 23 \\
\hline Pelidnota chalcothorax Perty, 1830 & 2 & & 2 \\
\hline Strategus sp. 71 & 1 & & 1 \\
\hline Mordellidae & East & West & Total \\
\hline Paramordellaria sp. 29 & 1 & & 1 \\
\hline Paramordellaria sp. 77 & & 1 & 1 \\
\hline Nitidulidae & East & West & Total \\
\hline Nitidulidae sp. 6 & 3 & & 3 \\
\hline Passalidae & East & West & Total \\
\hline Passalus interruptus (Linnaeus, 1758) & 10 & & 10 \\
\hline Scarabaeidae & East & West & Total \\
\hline Canthon sp. 38 & 1 & & 1 \\
\hline Coprophanaeus cyanescens (Olsoufieff, 1924) & 10 & & 10 \\
\hline Deutochilum sp. 30 & 1 & & 1 \\
\hline Deutochilum sp. 73 & 7 & 4 & 11 \\
\hline Deutochilum sp. 74 & & 26 & 26 \\
\hline Dichotomius sp. 72 & 167 & & 167 \\
\hline Eurysternus hypocrita Balthasar 1939 & 2 & & 2 \\
\hline
\end{tabular}


Table 2. Continuation.

\begin{tabular}{lccc}
\hline Staphylinidae & East & West & Total \\
\hline Deleaster sp. 21 & 1 & & 1 \\
\hline Tenebrionidae & East & West & Total \\
\hline Epitragini sp. 68 & 1 & 5 & 6 \\
Goniaderini sp. 49 & 1 & & 1 \\
Mylaris maxima (Germar, 1824) & 3 & & 3 \\
Scotinus sp. 75 & & 8 & 8 \\
Strongylium sp. 33 & 1 & & 1 \\
Tenebrionidae sp. 78 & & 5 & 5 \\
\hline Trogidae & East & West & Total \\
\hline Polynoncus vazdemelloi Huchet and Costa-Silva, 2018 & 1 & & 1 \\
\hline
\end{tabular}

Species richness and abundance differed between locations; an average of 2.79 species/ morphospecies per sample were collected at the eastern site, while the average number of species/ morphospecies per sample at the western site was two times lower. The same pattern was observed for the average abundance of individuals per sample; the eastern site had twice the number of individuals (6.87) than the western site (3.14). For both richness and abundance, the complete models had better fit than their respective null models (delta AIC $>2$ ). The site, controlling the effects of seasonality and locality, explained around $12 \%$ of the variation in richness $\left(\mathrm{R}^{2}\right.$ marginal $\left.=0.11\right)$ and abundance of beetles $\left(\mathrm{R}^{2}\right.$ marginal $\left.=0.12\right)$. Most of the variation can be explained by seasonality (temporal replicas) and transects (spatial replicas). Approximately 41\% of the average richness variation (conditional $\mathrm{R}^{2}=$ 0.41 ) and $\sim 30 \%$ of the average abundance variation (conditional $\mathrm{R}^{2}=0.30$ ) was explained, considering the random variables included in the models (Figure 2).
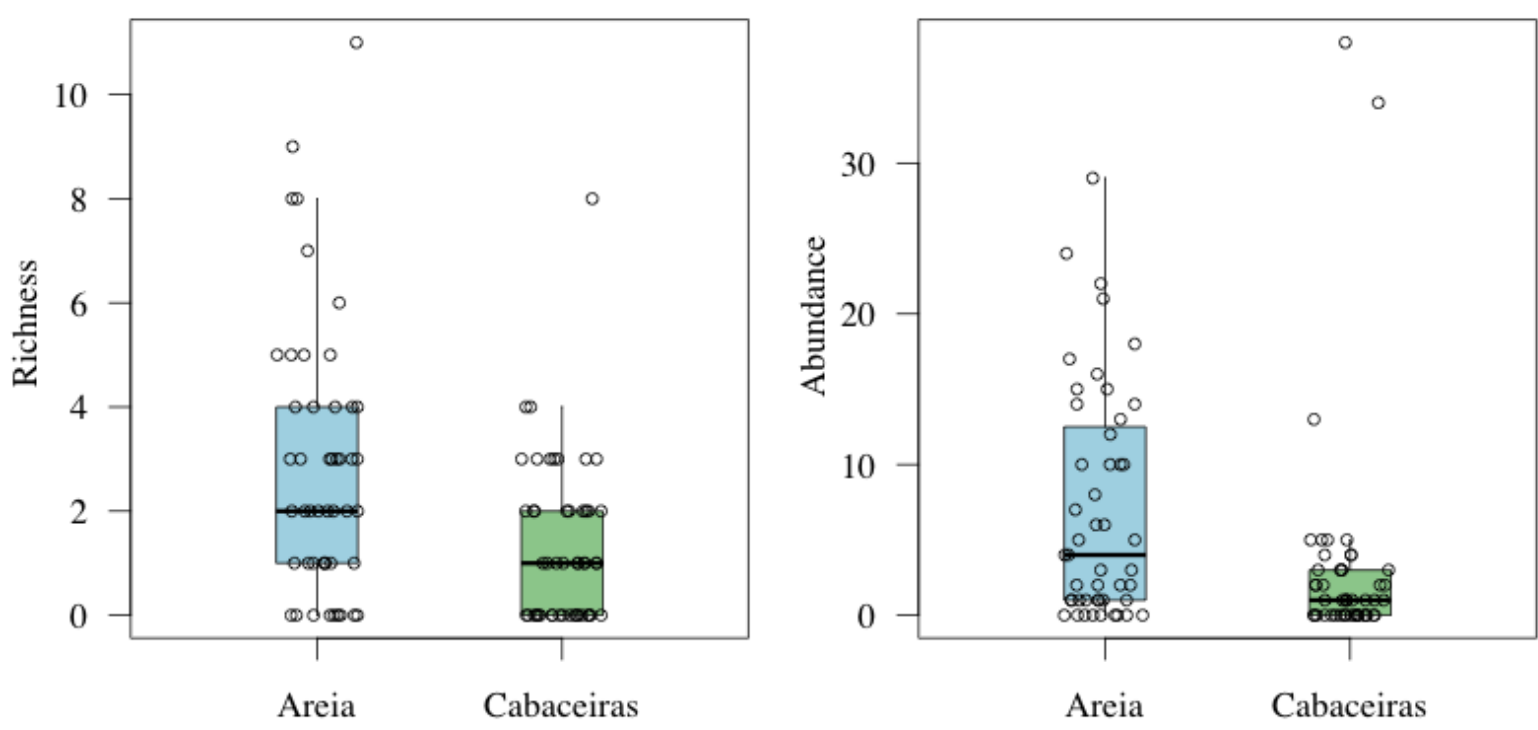

Figure 2. Number of species/morphospecies and abundance of coleopterans sampled at Areia (East) and Cabaceiras (West), Paraiba State, Brazil.

Our results support the conclusion that in Northeastern Brazil, the abundance and richness of insects is greater in humid areas than in more arid locations (WOLDA, 1992; VASCONCELLOS et al.,
2010; CREÃO-DUARTE et al., 2016). These climatic parameters are strongly affected by the positioning (east or west) on the Borborema Plateau, which causes changes in the beetle assemblages. 
Temperature is an important predictor of the distribution of beetle species in tropical areas, where most species have smaller ranges and lower thermal tolerance than in temperate areas, making them more susceptible to temperature variations (ANGILLETTA; NIEWIAROWSKI; NAVAS, 2002; HARRIS; RODENHOUSE; HOLMES, 2019; BARRETTO; SALOMÃO; IANNUZZI, 2019).
The rarefaction curves did not reach the asymptote, especially from east side (Areia) (Figure 3 ). However, 10 transects (approximately 2 months of collection) was sufficient to demonstrate that the number of accumulated species/morphospecies per collection event is lower in west face (Cabaceiras) than in Areia for any given sampling event.

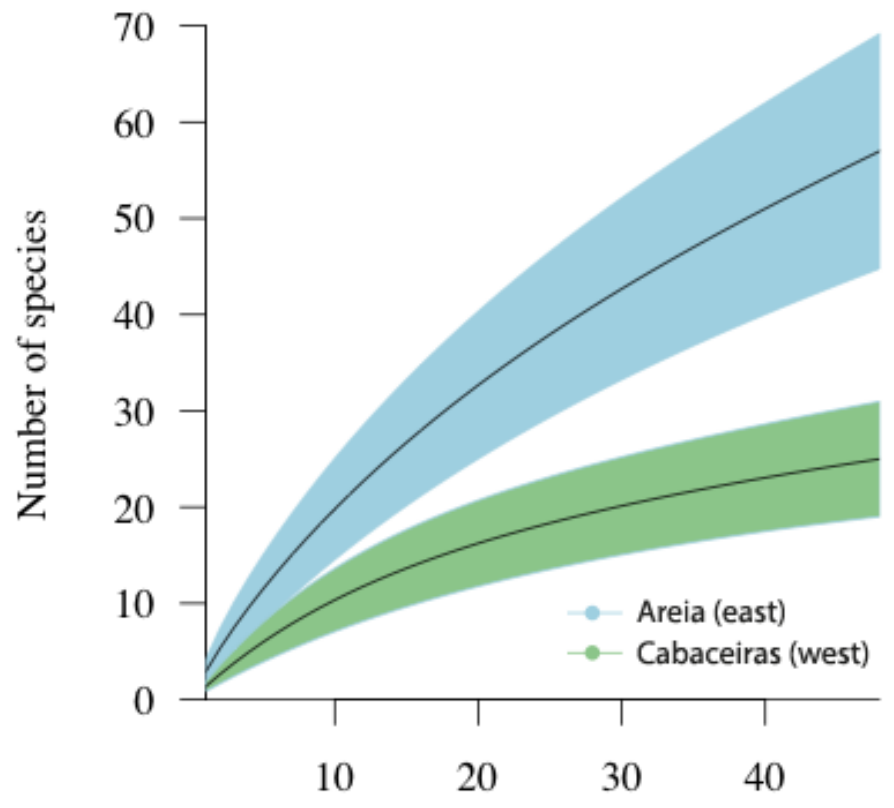

Transects

Figure 3. Species rarefaction curve by locality. The colour wrapped around the continuous lines represents $95 \%$ confidence interval.

We were able to sample only a portion of the total number of species/morphospecies from both areas, which is common for tropical areas. The rarefaction curves did not reach an asymptote, because when megadiverse taxa such as beetles are sampled, species richness is very likely to increase as more samples are incorporated (BUNGE; FITZPATRICK, 1993). However, comparing the two areas, on the east side (Areia), the rarefaction curve remained higher than on the west face (Cabaceiras), highlighting a higher species density in this area, regardless of the sampling effort employed.

The composition of beetle species was markedly different between the locations (PERMANOVA, $\mathrm{r}^{2}=0.098, \mathrm{p}=0.001$ ). Among the 75 species/morphospecies collected, 51 occurred exclusively on the east face of the plateau and 17 occurred exclusively on the west face. Only seven morphospecies were sampled in both areas. The low variation explained by PERMANOVA is related to the large number of singletons and doubletons. Among the total sampled species/morphospecies, 50 were collected only once or twice in the localities, with $35(47.29 \%)$ exclusive to the east face of the plateau, and $11(14.86 \%)$ to the west face (Figure 4).
Our data suggest that the markedly different environmental conditions (Figure 5) on opposing faces of the plateau may explain the differences in beetle species composition. The low overlap of species/morphospecies (9\%) (see Figure 5) between both localities and the many rare taxa sampled reinforce the hypothesis that most species in tropical mountains occur in small climatic zones (JANZEN et al, 1976) and that different rate of diversification can be driven by topography and climate. However, to further understand this interaction, additional tools will be needed to refine the identification and control of landscape parameters. For example, despite the fact that the pitfall traps were installed more than 3 $\mathrm{km}$ from the goat's stables in Cabaceiras site, which reduces the chance of catching dung beetles attracted by goat faeces, we cannot completely rule out the indirect effects of goat breeding or other economic activities on beetles' composition. An increase in taxonomic knowledge coupled with a deeper understanding of human impacts on the distribution of biodiversity in important to provide necessary information for conservation and environmental planning in this highly threatened environment. 


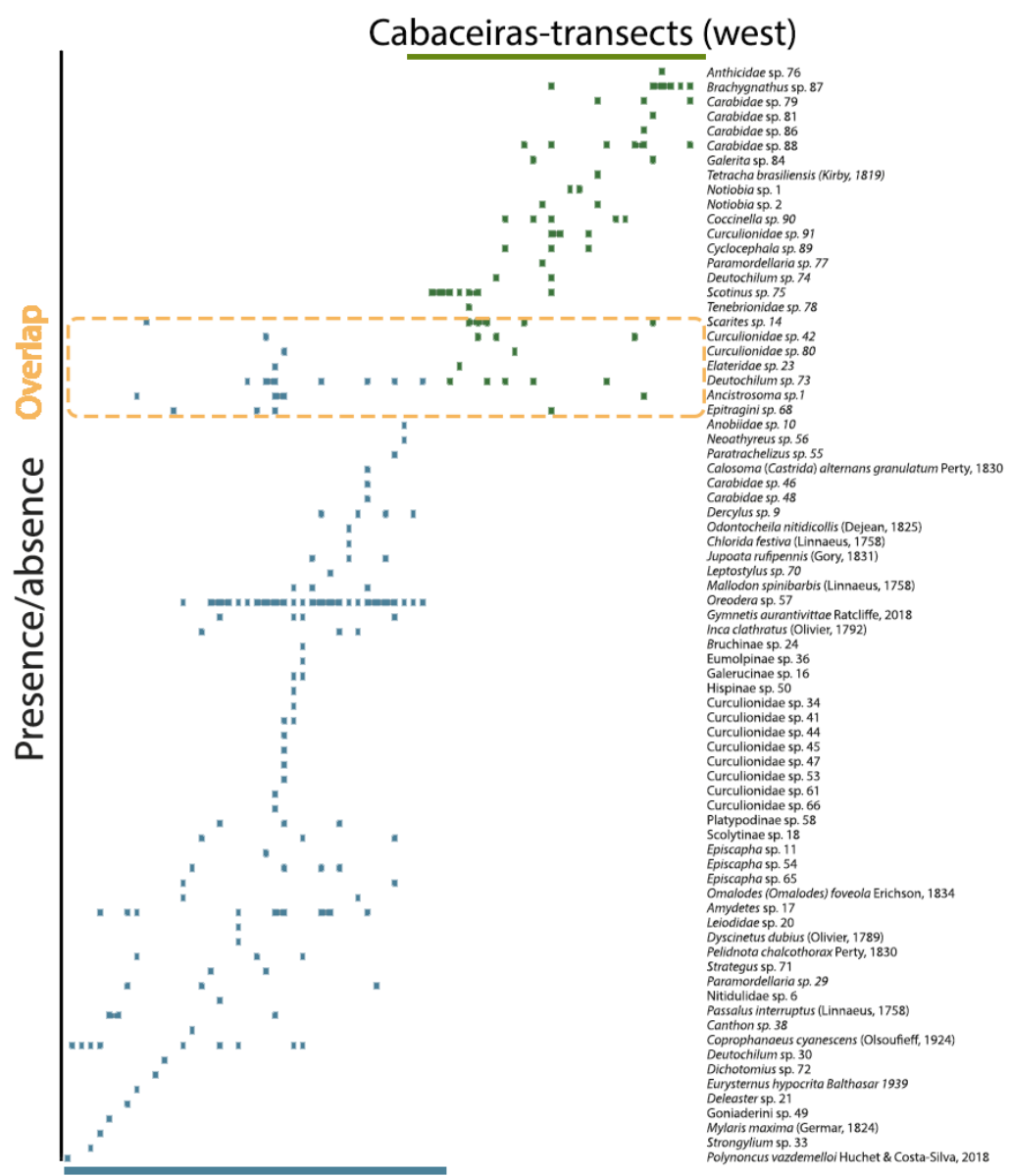

Areia-transects (east)

Figure 4. Presence/absence of species/morphospecies in east (blue bars - Areia) and west (green bars - Cabaceiras) faces of the Borborema Plateau, Paraíba State, Brazil. The dashed rectangle shows the beetle composition shared between the areas. Each column represents one transect and sequence was ordered based on beetle composition.

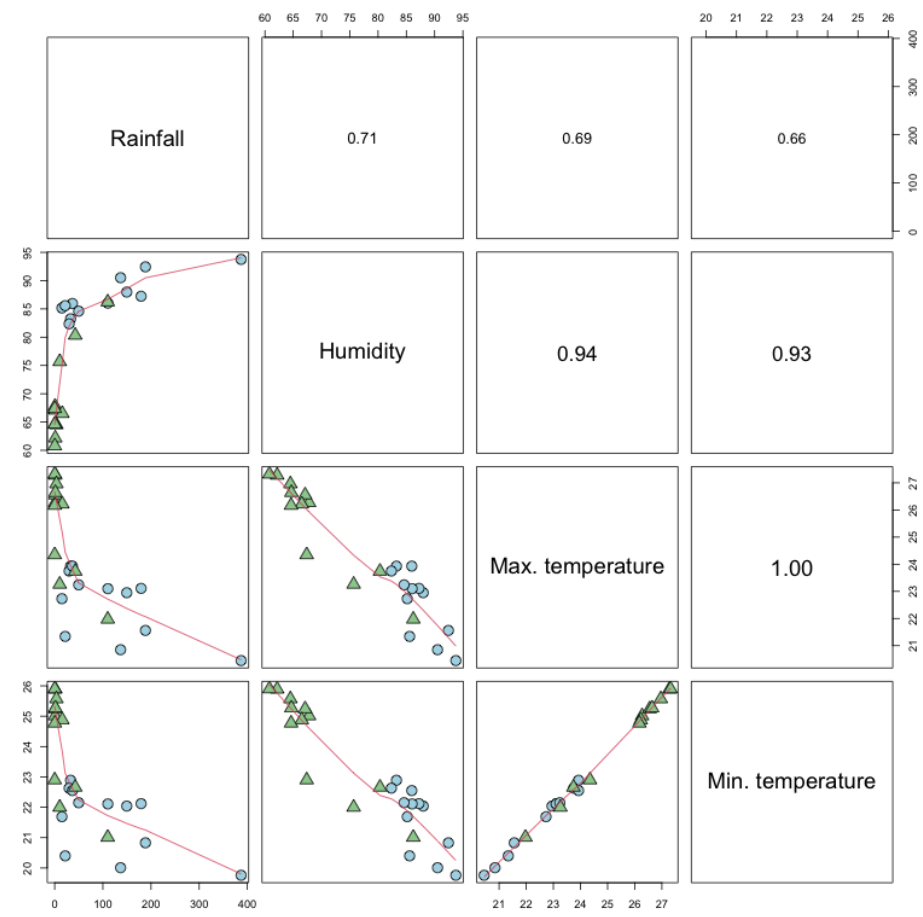

Figure 5. Pearson correlation between climatic variables from east (blue circle) and west (green triangle) faces of the Borborema Plateau, Paraíba, Brazil 


\section{CONCLUSION}

This study has shown that Borborema Plateau supports a very different beetle assemblage between the eastern and western areas. The variation in climate must be considered critical in maintaining and promoting high levels of beetle diversity in northeastern Brazil.

\section{ACKNOWLEDGEMENTS}

We thank Anderson, Ítalo, Luciene, Angélica, Matheus, Rangel, Diana, Vanusa, Joalisson, Nilton, Jordana, Carem and the LECA-UFPB team, especially Ernandes for the help during fieldworks. To the Laboratory of Invertebrate (LABIN) of the Centro de Ciências Agrárias of the Universidade Federal da Paraíba, Campus II for the structure and support. To the Coordenação de Aperfeiçoamento de Pessoal de Nível Superior CAPES/Brazil (Finance Code 001) and FAPEAM-Programa POSGRAD, which financed this study in part.

\section{REFERENCES}

AKAIKE, H. On the Fallacy of the Likelihood Principle. Statistics \& Probability Letters, 1: 7578, 1982.

ANDERSON, M. J. A new method for nonparametric multivariate analysis of variance. Austral Ecology, 26: 32-46, 2001.

ANDRADE-LIMA, D. The caatingas dominium. Revista Brasileira de Botânica, 4: 149-163, 1981.

ANDRADE, L. A. et al. Análise florística e estrutural de matas ciliares ocorrentes em brejo de altitude no município de Areia, Paraíba. Revista Brasileira de Ciências Agrárias, 1: 31-40, 2006.

ANGILLETTA, M. J.; NIEWIAROWSKI, P. H.; NAVAS, C. A. The evolution of thermal physiology in ectotherms. Journal of Thermal Biology, 27: 249 $-268,2002$.

ARNETT, R. H.; THOMAS, M. C. American Beetles, Volume I: Archostemata, Myxophaga, Adephaga, Polyphaga: Staphyliniformia. Boca Raton: CRC Press, 2000. v. 1.

ARNETT, R. H.; THOMAS, M. C. American Beetles, Volume II: Polyphaga: Scarabaeoidea through Curculionoidea. 2. ed. Boca Raton: CRC Press, 2002. v. 2.
BARRETTO, J.; SALOMÃO, R. P.; IANNUZZI, L. Diversity of dung beetles in three vegetation physiognomies of the Caatinga dry forest. International Journal of Tropical Insect Science, 40: 385-392, 2019.

BATES, D. et al. Fitting Linear Mixed-Effects Models using lme4. Journal of Statistical Software, 67: 1-51, 2015

BOLKER, B. M. et al. Generalised linear mixed models: a practical guide for ecology and evolution. Trends in Ecology \& Evolution, 24: 127-135, 2009.

BORGES, C. K. et al. Climatologia da precipitação no município de cabaceiras, PB período: 1926-2011. In: SIMPÓSIO BRASILEIRO DE CAPTAÇÃO E MANEJO DE ÁGUA DE CHUVA, 2012, Anais... Campina Grande-PB: Federação das Industrias do Estado da Paraíba. 2012. p. 5-8.

BUNGE, J.; FITZPATRICK, M. Estimating the number of species: A review. Journal of the American Statistical Association, 88: 364-373, 1993.

CELLI, N. G. R. et al. Chave de identificação e diagnose dos Histeridae (Insecta: Coleoptera) de interesse forense do Brasil. Iheringia. Série Zoologia, 105: 461-473, 2015.

COLEMAN, C. O. Taxonomy in times of the taxonomic impediment - examples from the community of experts on amphipod crustaceans. Journal of Crustacean Biology, 35: 729-740, 2015.

COLWELL, R. K. et al. Interpolating, extrapolating, and comparing incidence-based species accumulation curves. Ecology, 85: 2717-2727, 2004.

CREÃO-DUARTE, A. et al. Temporal Variation of Membracidae (Hemiptera: Auchenorrhyncha) Composition in Areas of Caatinga with Different Vegetation Structures. Sociobiology, 63: 826-830, 2016

EMBRAPA - Empresa Brasileira de Pesquisa Agropecuária. Levantamento Exploratório Reconhecimento de Solos do Estado da Paraíba; Interpretação para uso Agrícola dos Solos da Paraíba. Rio de Janeiro, RJ: DRN-SUDENE, 1972.

GIDASPOW, T. The genus Calosoma in Central America, the Antilles, and South America (Coleoptera, Carabidae). Bulletin of the American Museum of Natural History, 1963. v. 124, 39 p. 
GOTELLI, N. J.; COLWELL, R. K. Quantifying biodiversity: procedures and pitfalls in the measurement and comparison of species richness. Ecology Letters, 4: 379-391, 2001.

GUEDES ALCOFORADO-FILHO, F. et al. Florística e fitossociologia de um remanescente de vegetação caducifólia espinhosa arbórea em Caruaru, Pernambuco 1. Acta Botanica Brasilica, 17: 287303, 2003.

HARRIS, J. E.; RODENHOUSE, N. L.; HOLMES, R. T. Decline in beetle abundance and diversity in an intact temperate forest linked to climate warming. Biological Conservation, 240: 108219, 2019.

HARTIG, F. 2016. DHARMa: Residual Diagnostics for Hierarchical Regression Models. The Comprehensive R Archive Network. Disponível em: $\quad<$ http://florianhartig.github.io/DHARMa/>. Acesso em: 17 abr. 2018.

HERNÁNDEZ, M. I. M. Besouros Escarabeíneos (Coleoptera: Scarabaeidae) Da Caatinga Paraibana, Brasil. Oecologia Brasiliensis, 11: 356-364, 2007.

HORTAL, J. et al. Seven Shortfalls that Beset LargeScale Knowledge of Biodiversity. Annual Review of Ecology, Evolution, and Systematics, 46: 523$549,2015$.

HUCHET, J. B.; COSTA-SILVA, V. A new species of Polynoncus Burmeister, 1876 from Brazil (Coleoptera: Trogidae). Zootaxa, 4524: 553-566, 2018.

IANNUZZI, L.; MAIA, A. C. D.; VASCONCELOS, S. D. Ocorrência e sazonalidade de coleópteros buprestídeos em uma região de caatinga nordestina. Biociências, 14: 174-179, 2007.

INMET - Instituto Nacional de Meteorologia e Geofísica. Banco de Dados Meteorológicos. Disponível em: <http://www.inmet.gov.br/portal/>. Acesso em: 17 abr. 2017.

JANZEN, D. H. Why Mountain Passes are Higher in the Tropics. The American Naturalist, 101: 233249, 1967.

JANZEN, D. H .et al. Changes in the Arthropod Community along an Elevational Transect in the Venezuelan Andes. Biotropica, 8: 193-203, 1976.

JUNQUAS, C. et al. Influence of South America orography on summertime precipitation in Southeastern South America. Climate Dynamics, 46: 3941-3963, 2016.
LIBERAL, C. N. et al. How habitat change and rainfall affect dung beetle diversity in Caatinga, a Brazilian semi-arid ecosystem. Journal of Insect Science, 11: 1-11, 2011.

LUEDERWALDT, H. Monografia dos passalídeos do Brasil (Col.). Revista do Museu Paulista, 17: 1$262,1931$.

LYRA, G. B.; OLIVEIRA-JÚNIOR, J. F.; ZERI, M. Cluster analysis applied to the spatial and temporal variability of monthly rainfall in Alagoas state, Northeast of Brazil. International Journal of Climatology, 34: 3546-3558, 2014.

MAYO, S. J.; FEVEREIRO, V. P. B. Mata de PauFerro - A pilot study of the Brejo Forest of Paraiba, Brazil. Bentham - Moxon Trust. Kew, London, Royal Botanic Gardens. 1982.

NAKAGAWA, S.; SCHIELZETH, H. A general and simple method for obtaining R2 from generalised linear mixed-effects models. Methods in Ecology and Evolution, 4: 133-142, 2013.

NASCIMENTO, F. E. DE L.; BOTERO, J. P. Synopsis of the Neotropical genus Jupoata Martins \& Monné, 2002 (Coleoptera: Cerambycidae). Papeis Avulsos de Zoologia, 58: 6-9, 2018.

OLIVEIRA, F. X.; ANDRADE, L. A.; FÉLIX, L. P. Comparações florísticas e estruturais entre comunidades de Floresta Ombrófila Aberta com diferentes idades, no Município de Areia, PB, Brasil. Acta Botanica Brasilica, 20: 861-873, 2006.

PARENTE, H. N. et al. Impact of goat trampling on soil attributes in an area of caatinga. Revista Brasileira de Saúde e Produção Animal 11: 331341,2010

R CORE TEAM. R: A language and environment for statistical computing. R Foundation for Statistical Computing, Vienna, Austria., 2019.

RAHBEK, C. et al. Building mountain biodiversity: Geological and evolutionary processes. Science, 365: 1114-1119, 2019.

RANGEL, T. F. et al. Modelling the ecology and evolution of biodiversity: Biogeographical cradles, museums, and graves. Science, 361: 1-48, 2018.

RATCLIFFE, B. C. A Monographic Revision of the Genus Gymnetis MacLeay, 1819 (Coleoptera: Scarabaeidae: Cetoniinae). Bulletin of the University of Nebraska State Museum, 31: 1- 250, 2018. 
ROE, G. H. Orographic Precipitation. Annual Review of Earth and Planetary Sciences, 33: 645671, 2005.

ROTHEÁ, R. R. A. D. et al. Treehopper (Membracidae, auchenorrhyncha) assemblages in four semi-arid areas of caatinga of northeast Brazil. Biota Neotropica, 19: 1-7, 2019.

SANTOS, J.; ALMEIDA-CORTEZ, J.; FERNANDES, G. Diversity of gall-inducing insects in the high altitude wetland forests in Pernambuco, Northeastern Brazil. Brazilian Journal of Biology, 71: 47-56, 2011.

SILVEIRA, L. F. L.; MERMUDES, J. R. M. Systematic review of the firefly genus Amydetes Illiger, 1807 (Coleoptera: Lampyridae), with description of 13 new species. Zootaxa, 3765: 201248, 2014.

SOULA, M. Les Coléoptères du Nouveau Monde. Rutelini 3. Révision des Pelidnotina 3. Besoiro Saintry, FranceAEFCT, 2009.

SOUSA, R. C. J. Cladistic Analysis of Incini Burmeister, 1842 (Coleoptera, Scarabaeidae, Cetoniinae). p. 165 p, 2019.

SPIESSBERGER, E. L.; MERMUDES, J. R. M. Notes on the Distribution and Ovipositor Morphology of Mylaris gigas (Linnaeus, 1767), Mylaris maxima (Germar, 1824), and Taphrosomadohrni Kirsch, 1866 (Coleoptera: Tenebrionidae: Stenochiinae: Cnodalonini). The Coleopterists Bulletin, 72: 209-213, 2018.

TRIPLEHORN, C. A.; JOHNSON, N. F.; BORROR, D. J. Borror and Delong's Introduction to the Study of Insects. 7. ed. Belmont: Brooks/Cole Thomson, 2005, 888 p.

UVO, C.; BERNDTSSON, R. Regionalisation and spatial properties of Ceará State rainfall in northeast Brazil. Journal of Geophysical Research: Atmospheres, 101: 4221-4233, 1996.

VASCONCELLOS, A. et al. Seasonality of insects in the semi-arid Caatinga of northeastern Brazil. Revista Brasileira de Entomologia, 54: 471-476, 2010 .

VAZ-DE-MELLO, F. Z. et al. A multilingual key to the genera and subgenera of the subfamily Scarabaeinae of the New World (Coleoptera: Scarabaeidae). Zootaxa, 2854: 1-73, 2011.
VELOSO, H. P.; RANGEL FILHO, A. L. R.; LIMA, J. C. A. Classificação da Vegetação Brasileira Adaptada a um Sistema Universal. Rio de Janeiro, RJ: IBGE, 1991, 124 p.

WATT, J. C. A revised subfamily classification of Tenebrionidae (Coleoptera). New Zealand Journal of Zoology, 1: 381-452, 1974.

WOLDA, H. Trends in Abundance of Tropical Forest Insects. Oecologia, 89: 47-52, 1992. 